\title{
RAPID DIAGNOSTIC OF FISH FLAVOBACTERIOSIS USING POLYMERASE CHAIN REACTION
}

Rud Yu. P.

Institute of Fisheries, NAAS of Ukraine

\author{
135, Obukhivska str., Kyiv, 03164, Ukraine \\ e-mail: rud_yuriy@ifr.com.ua
}

The method of rapid identification of fish flavobacteriosis using polymerase chain reaction (PCR) was developed. Specifity and efficiency of the selected oligonucleotide primers was confirmed. Nine Flavobacterium strains were isolated from clinically healthy and infected with Flavobacteriosis rainbow trout Onchorhynchus mykiss. Flavobacterium columnare strain was identified using the developed rapid diagnosis method. Phylogenetic analysis had indicated the kinship of isolated strains to Flavobacterium genera. Neither F. psychrophylum or F. branchiophilum strains were identified in the isolated samples. The species identification capacity using the $16 \mathrm{~S} r R N A$ gene restriction analysis was shown. The developed PCR method can be used for rapid identification of different fish flavobacteriosis forms in fish farms in Ukraine.

Key words: Flavobacteriosis, rainbow trout, PCR.

The genus Flavobacterium is characterized with gram-negative, aerobic, oxidasepositive, nonenzymatic, yellow-pigmented and mostly gliding bacteria that do not form spores [1]. Over the past 10 years Flavobacterium genus was replenished with many new species and now includes 75 species. These microorganisms inherent such ecological niches as fresh and brackish waters and soils [2]. Most of Flavobacterium genus representatives are pathogens or opportunistic infections agents that infect large range of organisms, including plants, fish and humans [3-5]. F. psychrophylum and F. columnare are the most hostile representatives of the Flavobacterium genus in fish culture, leading to the mass death of fish in fish farms $[6,7]$.

Bacteria $F$. psychrophylum is the agent of infectious disease of salmon called "Bacterial cold water disease" (BCWD) [8] and cause liver inflammation in juvenile rainbow trout fish (Rainbow trout fry disease, RTFS) [9]. These diseases are prevalent in Scandinavian countries, but can be also found in cold water farms in central and eastern Europe [10]. The main sign of $F$. psychrophylum infection is the formation of deep ulcers on the body surface of infected fish.

Columnaris or cotton-wool disease, caused by bacterial pathogen $F$. columnare is infectious and highly contagious disease, that cause massive loss of freshwater fish species. This disease develops at a temperature of $15{ }^{\circ} \mathrm{C}$ and above and is found in salmon, channel catfish, carp and others [11]. Often columnaris disease comes out as a result of secondary or opportunistic infection [12]. The appearance on the fish flesh of pale whitish areas that resemble balls of wool or cotton are among the disease signs. During the course of the columnaris disease affected fish gills become of pale shade with necrotic areas. In juveniles the disease can occur without typical symptoms. Previously it was thought that this disease is caused by a complex bacterial infection formed by 
Flexibacter columnaris, Bacillus columnaris, Chondrococcus columnaris and Cytophaga columnaris. Also it was mistakenly believed that given disease has fungal etiology [13].

Another flavobacteriosis agent is bacteria $F$. branchiophilum, causing bacterial gill disease (BGD) of trout [14]. Besides the above mentioned species, flavobacteriosis and fish mortality is also associated with other representatives of the Flavobacterium genus, like, $F$. johnsoniae, F. aquatile, $F$. hydatis and $F$. succinicans $[2,15,16]$.

One of the key factors of the rapid development of global aquaculture is the control of infectious diseases in breeding facilities. In Ukraine the situation with the distribution and origin of flavobacteriosis in natural waters and fishery enterprises does not fully investigated. Moreover, this bacterial disease is stated to be one of the most dangerous in modern aquaculture. The purpose of given research was to isolate bacteria of Flavobacterium genus from infected and clinically healthy rainbow trout Onchorhynchus mykiss and develop a rapid diagnostic method of fish flavobacteriosis using polymerase chain reaction (PCR).

Materials and methods. Initial isolation of microorganisms from juvenile rainbow trout $O$. mykiss suspected of flavobacteriosis disease was performed on meat peptonic agar (MPA). Samples for bacteriological studies were taken from gills, skin and abdominal cavity. Similar studies were carried out also for clinically healthy rainbow rainbow trout. Isolation of pure culture, colonies and cell morphology research were performed by conventional methods [17].

DNA was extracted from the pure cultures colonies. For this, the bacterial suspensions were prepared. Bacteria were inserted into the $100 \mu 1$ of phosphate buffer (137 mM NaCl, $2.7 \mathrm{mM} \mathrm{KCl}, 10 \mathrm{mM} \mathrm{Na} 2 \mathrm{HPO}_{4}, 2 \mathrm{mM} \mathrm{KH}_{2} \mathrm{PO}_{4}, \mathrm{pH}$ 7.4) with sterile needle. 500 microliter of lysis buffer (10 mM TRIS-HCl pH 8.0, $0.1 \mathrm{M} \mathrm{NaCl}, 25 \mathrm{mM}$ EDTA, $0.5 \%$ sodium dodecyl sulfate) and $3 \mathrm{ml}$ of proteinase $\mathrm{K}(\sim 600$ units $/ \mu \mathrm{l})$ were added, thoroughly mixed and incubated for 1 hour at $37^{\circ} \mathrm{C}$. DNA was extracted with phenol $(\mathrm{pH} \mathrm{8.0)}$ and centrifuged for 5 minutes at $13400 \mathrm{rpm}$. The supernatant was collected and was used for subsequent DNA extraction with a mixture of chloroform isoamyl alcohol (24:1). The suspension was centrifuged at microcentrifuge for five minutes at $13400 \mathrm{rpm}$. 0.1 volume of $3 \mathrm{M}$ sodium acetate $(\mathrm{pH} \mathrm{5.2)}$ and 2.5 volume of cooled to $-20{ }^{\circ} \mathrm{C}$ ethanol were added to supernatant. DNA precipitation was carried out at room temperature for 1 hour. Then samples were centrifuged at $13400 \mathrm{rpm}$ for 10 minutes. DNA precipitate was washed with $70 \%$ ethanol. Received DNA samples were than dissolved in deionized water free of nucleases [18].

In order to develop oligonucleotide primers specific to bacteria - agents of flavobacteriosis, determine their specificity and physical properties the Vector NTI 10 software was used. In addition, primers specificity was tested using the online BLAST service (www.ncbi.nim.nih.gov/blast). The sequence of primers for F. columnare was FCF 5'-AAGGCAACGATGGGTAG-3' and FCR 5'-GCACGGAGTTAGCCGATC-3'. Half-nested PCR was used for F.psychrophylum diagnosis. The following set of primers: FP1 5'-CTTAGTTGGCATCAACAC-3' and FP3 5'ACACTGGCAGTCTTGCTA-3' was used during the first stage of half-nested PCR, while PSY1 5'- GTTGGCATCAACACACT-3 'and FP3 - during the second stage.

For identification of the Flavobacterium genus bacteria the restriction fragment length polymorphism method of PCR products (PCR-RFLP) was used [19]. The 
amplification of $16 \mathrm{~S}$ rRNA gene was perfomed with the following primers: $27 \mathrm{~F}$ 5'AGAGTTTGATCMTGGCTCAG-3' and 1492R 5'-CCGYTACCTTGTTACGACTT-3'.

Amplification was performed on amplifier "96 Universal Gradient PEQ STAR» (PEQLAB, Germany). The reaction mixture had consisted of the following components: $12.5 \mathrm{ml}$ DreamTaq ${ }^{\mathrm{TM}}$ Green PCR Master Mix (2X) (Thermo Scientific), oligonucleotide primers (Metabion, Germany) - $1 \mathrm{~mm}$ of each $(20 \mathrm{pmol} / \mathrm{ml}), 1 \mathrm{ml}$ of sample DNA and sterile deionized water used to bring the total volume to $25 \mathrm{ml}$. Amplification included 1 cycle of prior denaturation at $94{ }^{\circ} \mathrm{C}\left(3\right.$ minutes) and 35 cycles of denaturation at $94{ }^{\circ} \mathrm{C}$ (30 seconds), primer annealing at $64{ }^{\circ} \mathrm{C}$ (30 seconds), synthesis at $72{ }^{\circ} \mathrm{C}(1$ minute) and extra synthesis cycle at $72{ }^{\circ} \mathrm{C}(7$ minutes $)$. After PCR the products were analyzed on $2 \%$ agarose gels in TAE buffer (40 mM TRIS-HCl, $20 \mathrm{mM}$ acetic acid, $1 \mathrm{mM}$ EDTA) and observed in UV transilluminator.

During the restriction analysis of $16 \mathrm{~S}$ rRNA gene of flavobacteria the restriction endonucleases HindIII and BamHI (Fermentas) were used. $10 \mathrm{ml}$ amplified DNA, $2 \mathrm{ml}$ buffer and $1 \mathrm{ml}$ of corresponding restrictions enzyme were inserted into microtube. The total volume was adjusted to $20 \mathrm{ml}$ with sterile deionized water. The mixture was left to react overnight in an incubator at $37{ }^{\circ} \mathrm{C}$. Restriction products were analyzed on $2 \%$ agarose gel with the addition of ethidium bromide at a concentration $0.5 \mathrm{~g} / \mathrm{cm}^{3}$. Electrophoresis was performed in TAE buffer ( $40 \mathrm{mM}$ TRIS-HCl, $20 \mathrm{mM}$ acetic acid, 1 $\mathrm{mM}$ EDTA) on the device for horizontal electrophoresis «Scie-Plus» in $100 \mathrm{~V}$ mode for two hours using 100 base pairs of DNA marker (Fermentas). The results were recorded by ultraviolet radiation photographing in transilluminator UVT1 «Biokom». Analysis of electrophoregramme was performed using TotalLab TL120 v2008.01software package.

DNA isolation from the gel was performed using a set of Silica Bead DNA Gel Extraction Kit (Fermentas) according to the manufacturer's protocol. Amplified fragments were examined on an automatic DNA sequenator 3130 Genetic Analyser (Applied Biosystems) using a sequencing kit BigDye ${ }^{\circledR}$ Terminator v3.1 Cycle Sequencing Kit. The nucleotide sequences analysis was performed using ClustalW algorithm in the software MEGA 5.2 and BLASTN.

Results and discussion. For microbiological studies 9 strains of Flavobacterium genus bacteria were isolated from clinically healthy and infected with flavobacteriosis rainbow trout $O$. mykiss. At MPA flavobacteria were shaped in a bright yellow colonies of different morphology. At Gram staining all isolated flavobacteria were gram negative. The cells were rod-shaped with pointed ends.

The results have confirmed that selected oligonucleotide primers specific for $F$. columnarae bacteria, had amplified the DNA fragment of expected size. Amplicon size was about 200 base pairs (Fig. 1). Oligonucleotides specific to $F$. columnarae were selected for amplification of 16S rRNA gene fragment. It was established that four out of nine flavobacteria isolates had belonged to $F$. columnarae, as evidenced by specific PCR amplification (Fig. 1). These samples were selected from infected fish with flavobacteriosis signs, namely in the form of columnaris disease. Gills of infected fish used for microbiological studies had shown the necrotic signs. Amplification specificity was tested using nucleotide analysis of PCR products. Sequence results had indicated that the amplified fragment corresponded to $16 \mathrm{~S}$ rRNA gene of $F$. solumnarae bacteria. 
It was impossible to diagnose $F$. psychrophylum bacteria using half-nested PCR. Given the fact that the symptoms had pointed at flavobacteriosis infection caused by $F$. columnarae, none of the samples, including clinically-healthy fish, was not infected with $F$. psychrophylum bacteria. It is also should be noted that $F$. psychrophylum is often diagnosed in asymptomatic fish, indicating on the circulation of the pathogen in the fish body [20].

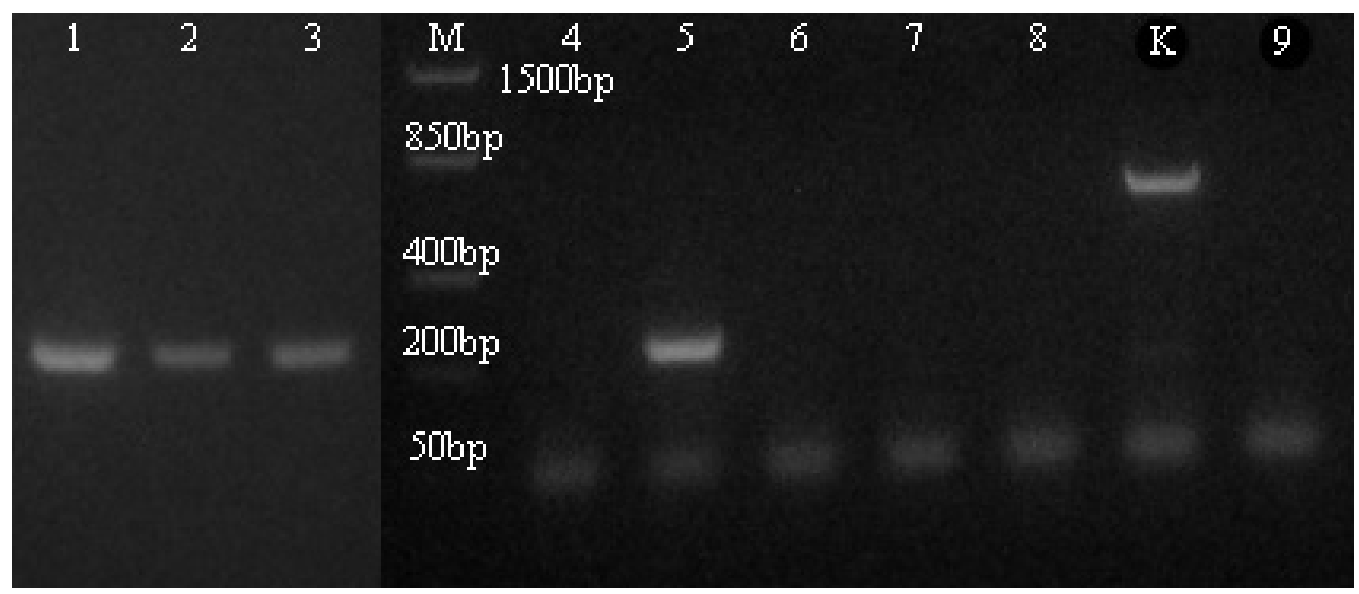

Fig. 1. Amplification of 16S rRNA gene fragment of $F$. columnarae bacteria: 1-9 samples of flavobacteria isolated from rainbow trout $O$. mykiss; $\mathrm{K}$ - control (amplification fragment of $\beta$-actin gene of rainbow trout); M - DNA marker (FastRuler Low Range DNA Ladder).

In order to identify species belonging of the flavobacteria isolates the PCR-RFLP was used. After amplification of 16S rRNA gene fragments (Fig. 2) the PCR products were used for restriction analysis. Analysis of the nucleotide sequences of 16S rRNA gene of flavobacteria had indicated the possibility of using two restriction endonucleases HindIII and BamHI for identification of F. psychrophylum, F. branchiophilum and $F$. columnarae bacteria. The $16 \mathrm{~S}$ rRNA gene sequence of $F$. psychrophylum does not have restriction sites for HindIII and BamHI, while $16 \mathrm{~S}$ rRNA gene of $F$. branchiophilum, by contrast, was hydrolyzed by both enzymes. The nucleotide sequence of $16 \mathrm{~S}$ rRNA gene of $F$. columnarae has only Bam HI restriction site.

Studies indicate that the nucleotide sequence of full-length 16S rRNA gene amplicons from isolated $F$. columnarae were restriction sites for BamHI. Amplicons of 16S rRNA gene of other four strains of isolated flavobacteria were also hydrolyzed with BamHI restriction enzyme. Location of restriction site and size of the products were identical for all strains of $F$. columnarae and Flavobacterium sp. (Table 1). It should be noted that in most flavobacteria, and other bacteria $16 \mathrm{~S}$ rRNA gene is very conservative and has about $99 \%$ identity. Its downside is that the other Flavobacterium species, containing only restriction site BamHI cannot be identified using this method. An analysis of $16 \mathrm{~S}$ rRNA gene sequences of the Flavobacterium genus representatives, had shown that other opportunistic flavobacteria except for $F$. columnarae belong to this group $-F$. johnsoniae, $F$. aquatile, $F$. hydatis and $F$. succinicans. The only amplicon of 16S rRNA gene from studied flavobacteria contained HindIII restriction site (Table 1). Study of nucleotide sequence of the DNA fragment had showed that RT021FU strain of 
Flavobacterium sp. belongs to the Flavobacterium oncorhynchi kind (Fig. 3). According to the literature data $F$. oncorhynchi is found in normal flora of rainbow trout $O$. mykiss [16].

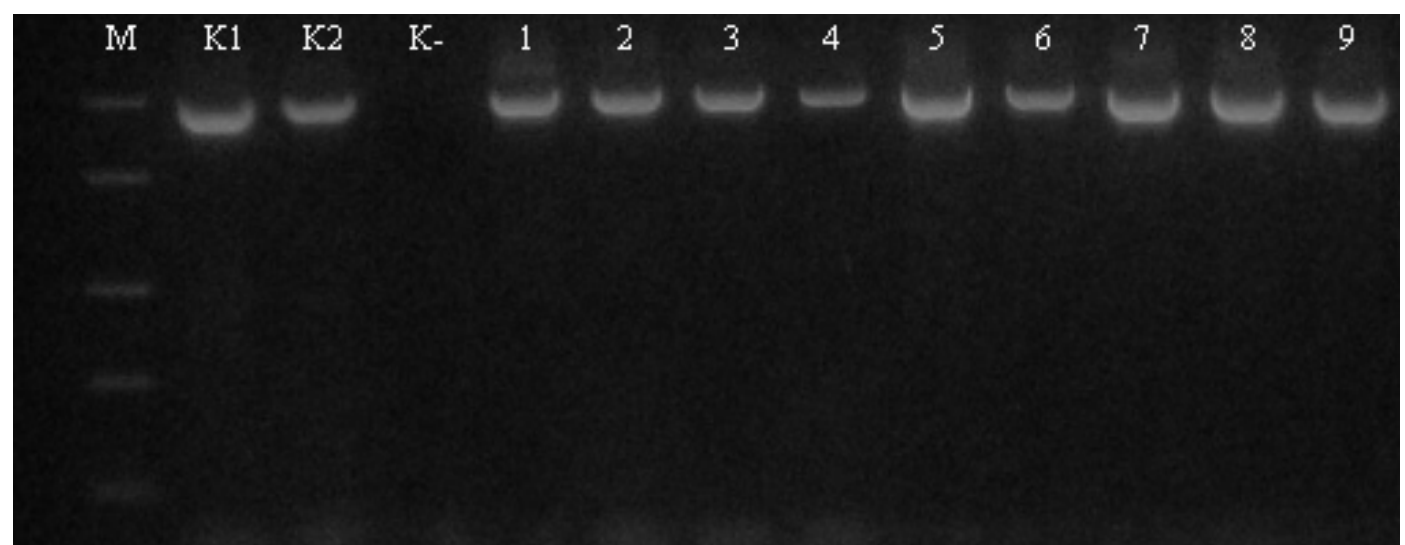

Fig. 2. Amplification of full-length 16S rRNA gene of flavobacteria isolated from rainbow trout $O$. mykiss:

1-9 - samples of flavobacteria isolated from rainbow trout O. mykiss; K1 and K2 -

positive controls (DNA of Aeromonas hydrophila and Yersinia ruckeri bacteria, respectively); $\mathrm{K}$ - control (all reaction components except for DNA); M - DNA marker (FastRuler Low Range DNA Ladder).

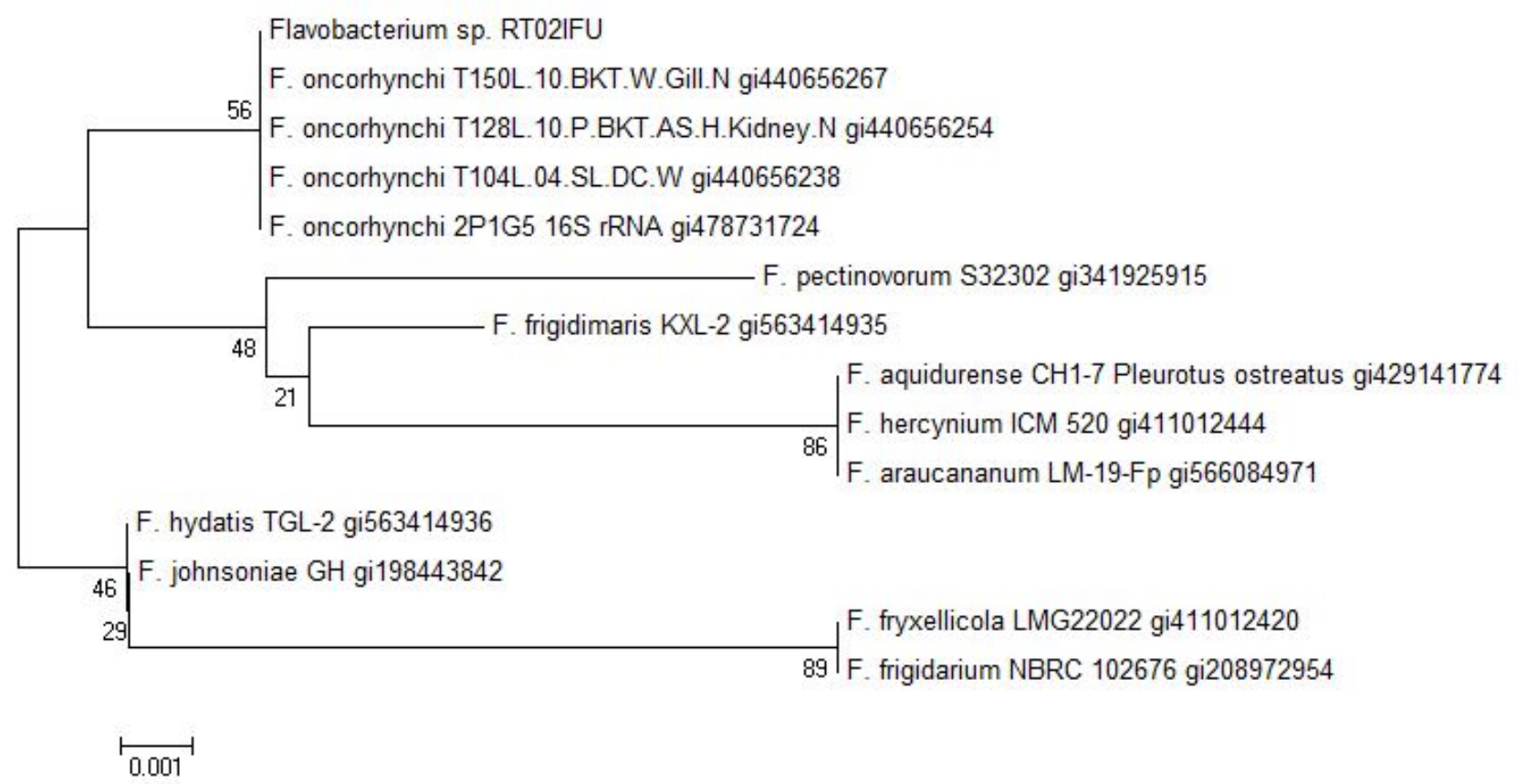

Fig. 3. Phylogenetic analysis of $16 \mathrm{~S}$ rRNA gene of Flavobacterium sp. strain RT021FU, isolated from rainbow trout $O$. mykiss. The tree was constructed using the Neighborjoining algorithm of MEGA software package version 5.2.

Despite the importance of flavobacteriosis for modern fishery and numerous investigation of its agents, only a small fraction of the data on pathogen-host interactions can be found in the literature. Among still unresolved questions remain the colonization of the skin and gills with flavobacteria, the formation of necrotic ulcers and reasons of 
high fish mortality. Diagnosis methods for this disease progresses rapidly and today the identification of the pathogen with only a few microbial cells is possible. Another important question coming next to the diagnosis is determination of virulence of flavobacteria strains. Nucleotide sequencing analysis of the bacteria genomes of the Flavobacterium genus can help in addressing this issue. Only at the presence of DNA sequences of flavobacteria, their genes that are responsible for cell virulence the study of the disease pathogenesis will become possible. Such studies are being performed, but their effectiveness will increase with the expansion of cooperation between reference laboratories [10].

Table 1. Restriction analysis of $16 \mathrm{~S} r R N A$ gene of flavobacteria isolated from rainbow trout O. mykiss.

\begin{tabular}{|l|l|c|c|}
\hline Strain & Flavobacteria species & BamHI & HindIII \\
\hline 1 & Fl. columnare & + & \\
\hline 2 & Fl. columnare & + & \\
\hline 3 & Fl. columnare & + & \\
\hline 4 & Fl. columnare & + & \\
\hline 5 & Fl. oncorhynchi & & + \\
\hline 6 & Fl. $s p$. & + & \\
\hline 7 & Fl. $s p$. & + & \\
\hline 8 & Fl. $s p$. & + & \\
\hline 9 & Fl. $s p$. & + & \\
\hline
\end{tabular}

Given the commonly increasing phenomenon of antibiotics resistance, research against flavobacteriosis should be focused on the control of the disease and prevention maintenance. Strict compliance with the rules of aquaculture, such as compliance with sanitary and epidemiological norms, fish stocking density and water quality will be the first steps to make. Vaccines, chemotherapy and probiotics - are also promising areas of the disease prevention. Perspective is the cultivation of species resistant to flavobacteriosis. Information about the flavobacteria pathogenesis will allow development of new methods against this disease that will be economically reasonable and safe for the environment and aquaculture facilities.

Thus, nine flavobacteria strains were isolated from clinically healthy and infected with flavobacteriosis rainbow trout $O$. mykiss. Using the method of express diagnostics based on PCR the four strains of $F$. columnarae were identified. Amplification specificity was tested using the method of nucleotide sequence analysis of amplified products and by restriction analysis of $16 \mathrm{~S}$ rRNA gene fragments. The results obtained have indicated that the developed PCR method can be used for rapid diagnosis of various forms of fish flavobacteriosis in fishery enterprises in Ukraine. Also, using the restriction and sequencing detected analyses the bacterial strain $F$. oncorhynchi was identified, which is representative of the normal flora of rainbow trout $O$. mykiss. Using the specific primers, other agents of flavobacteriosis such as $F$. psychrophylum and $F$. branchiophilum were not identified. For their diagnosis the geography of natural water resources and fisheries enterprises should be expanded, which will be the subject of our further research. 